\title{
Viral Satellite RNA Expression in Transgenic Tomato Confers Field Tolerance to Cucumber Mosaic Virus
}

John R. Stommel, Research Geneticist, Vegetable Laboratory, and Marie E. Tousignant, Chemist, and Thanda Wai, Research Associate, Molecular Plant Pathology Laboratory, USDA-ARS, Plant Sciences Institute, Beltsville, MD 20705; Rita Pasini, Faculty Research Assistant, Center for Agricultural Biotechnology, University of Maryland, College Park 20740; and Jacobus M. Kaper, Research Chemist, Molecular Plant Pathology Laboratory, USDA-ARS, Plant Sciences Institute, Beltsville, MD 20705

\begin{abstract}
Stommel, J. R., Tousignant, M. E., Wai, T., Pasini, R., and Kaper, J. M. 1998. Viral satellite RNA expression in transgenic tomato confers field tolerance to cucumber mosaic virus. Plant Dis. 82:391-396.

Field trials of transgenic tomato plants expressing an ameliorative satellite RNA of cucumber mosaic virus (CMV) were conducted to test the efficacy of satellite-transgenic technology to protect against CMV infection. Three transgenic tomato lines derived from two susceptible genotypes were evaluated over two growing seasons for viral symptoms and titers, satellite RNA expression, and fruit yield. Satellite-transgenic lines exhibited mild or no CMV symptoms and low viral titers relative to nontransformed plants. A significant negative correlation between satellite RNA levels and disease severity was evident in transgenic lines. Total marketable yield of CMV-infected satellite-transgenic lines was 40 to $84 \%$ greater than that of CMV-infected parent lines. Importantly, yield of CMV-infected satellite-transgenic lines did not differ significantly from mock-inoculated parent lines. Risk assessment results demonstrated low levels of satellite RNA transmission within the test site and no evidence of satellite RNA-induced damage on surrounding plants.
\end{abstract}

Additional keywords: biocontrol, CARNA 5, Lycopersicon esculentum

The development of techniques for genetic transformation of crop plants has provided the means to produce transgenic plants that express viral genes that disrupt viral infection or symptom development. These engineered plants are resistant to specific plant viruses and are promising for use in control of viruses such as cucumber mosaic virus (CMV), where conventional measures, including resistant plant cultivars, chemical control of the insect vector, and cross-protection with mild virus strains, have not proven successful in preventing CMV infections or epidemics. Transgenic tomato (8), melon (12), cucumber (13), and tobacco (5) plants expressing CMV coat protein genes have been described that exhibit varying degrees of resistance to CMV. The demonstrations by Waterworth et al. (44) and Mossop and Francki (31) that the presence of a lowmolecular-weight satellite RNA of CMV may ameliorate CMV symptoms suggested

Corresponding author: John R. Stommel

E-mail: jstommel@asrr.arsusda.gov

Accepted for publication 19 December 1997.

Publication no. D-1998-0123-01R

This article is in the public domain and not copyrightable. It may be freely reprinted with customary crediting of the source. The American Phytopathological Society, 1998. that viral satellite RNAs might be utilized as biocontrol agents for CMV.

CMV causes disease in a wide variety of economically important crops and has been described as one of the most damaging viruses of field-grown vegetable crops worldwide (41). Susceptible plants may exhibit stunting, chlorosis, and distortion of leaves, flowers, and fruit, resulting in decreased crop quality and yield. In the United States, serious CMV infections of tomato, pepper, and cucurbits have been reported in California, New York, New Jersey, and the southeastern states $(6,7,14,25)$. During the summer of 1992 , a severe CMV epidemic of tomato occurred in Alabama and reduced production up to $25 \%$ in affected areas (35). Extreme levels of viral disease occurred again in 1993 with similar consequences (36). CMV remained a constant problem to tomato production in Alabama through the 1996 growing season (E. J. Sikora, personal communication). Recent outbreaks of CMV in processing tomatoes have been reported in California's San Joaquin Valley (38). In East Asia, CMV infections are endemic $(34,40)$ and have occurred on epidemic scales in the Mediterranean region, including the countries of Italy, Spain, France, Greece, and Egypt $(9,17,27)$.

Although lethal tomato necrosis epidemics were reported as early as 1972 $(27,33)$ and isolated satellite RNA was first demonstrated experimentally to induce severe foliar necrosis in infected plants in 1977 (24), the involvement of CMV satellite RNAs as causal agents in these necrosis epidemics was not proven directly until similar epidemics recurred in Italy and Spain $(9,10,17,21)$. In addition to a tripartite RNA genome accompanied by at least one subgenomic RNA, these CMV isolates contained one or more linear satellite RNAs, referred to as CARNA 5 (CMV Associated RNA 5). CARNA 5 is not part of the viral genome but is dependent on the viral genomic RNA for its replication. Unlike early characterization of satellite RNA-induced necrosis, the majority of the 40 CMV satellite RNA sequence variants that have been described attenuate CMV symptoms on tomato and other host crop plants. The mechanism by which CARNA 5 modulates symptom development is not clearly understood, but it seems to be linked to the competition of CMV-RNA and CARNA 5 for the virally encoded RNA-dependent RNA polymerase or replicase enzyme $(18,45)$. The presence of CARNA 5 often results in a symptomless, low level of CMV infection in the plant, characterized by low virus titers.

Jacquemond and Leroux (16) were the first to report that tomato plants preinoculated with a mild CMV strain containing a nonnecrogenic CARNA 5 were protected when challenge-infected by a virulent strain of CMV. The preinoculation technology was successfully field tested in the United States, Italy, Japan, and China $(11,30,34,40)$ on a number of vegetable crops and is in commercial use in Japan and China, where it is government licensed and in practical use on a large scale.

Successful satellite RNA-mediated protection against $\mathrm{CMV}$ in transgenic plants expressing an ameliorative CMV satellite transgene has been demonstrated in tobacco (15), petunia (26), and tomato (29). In controlled environments, McGarvey et al. (29) noted little difference in symptoms between CMV-infected satellite transgenic tomatoes and uninfected nontransgenic plants, and a 10-fold decrease in virus titers in infected satellite transgenic tomatoes compared with unprotected plants. This report describes the results of the first APHIS-approved field trials conducted in the United States to test the efficacy of 
satellite-based CMV resistance in satellitetransgenic tomato genotypes.

\section{MATERIALS AND METHODS}

Plant materials and challenge inoculations. Transformation of the determinate tomato variety UC82B with a satellite RNA construct was previously described (29). These UC82B transformants exCARNA 5 satellite (CMV Associated RNA 5 from CMV strain S). Transformants were obtained via Agrobacterium tumefaciensmediated transformation of tomato leaf pressed RNA unique to the benign $\mathrm{S}$ -

tissue with a plasmid containing the NPT II gene under the control of the NOS promoter and terminator and the GUS gene under the control of the CaMV $35 \mathrm{~S}$ promoter and NOS terminator. Inserted between the CaMV $35 \mathrm{~S}$ promoter and the open reading frame of the GUS gene is a cDNA copy of the ameliorative CMV satellite S-CARNA 5 (1). Regenerated plants containing the inserted DNA were identified via polymerase chain reaction (PCR) using primers specific for the CMV satellite RNA insert (28). In addition to the SCARNA 5 transgenic UC82B genotype,

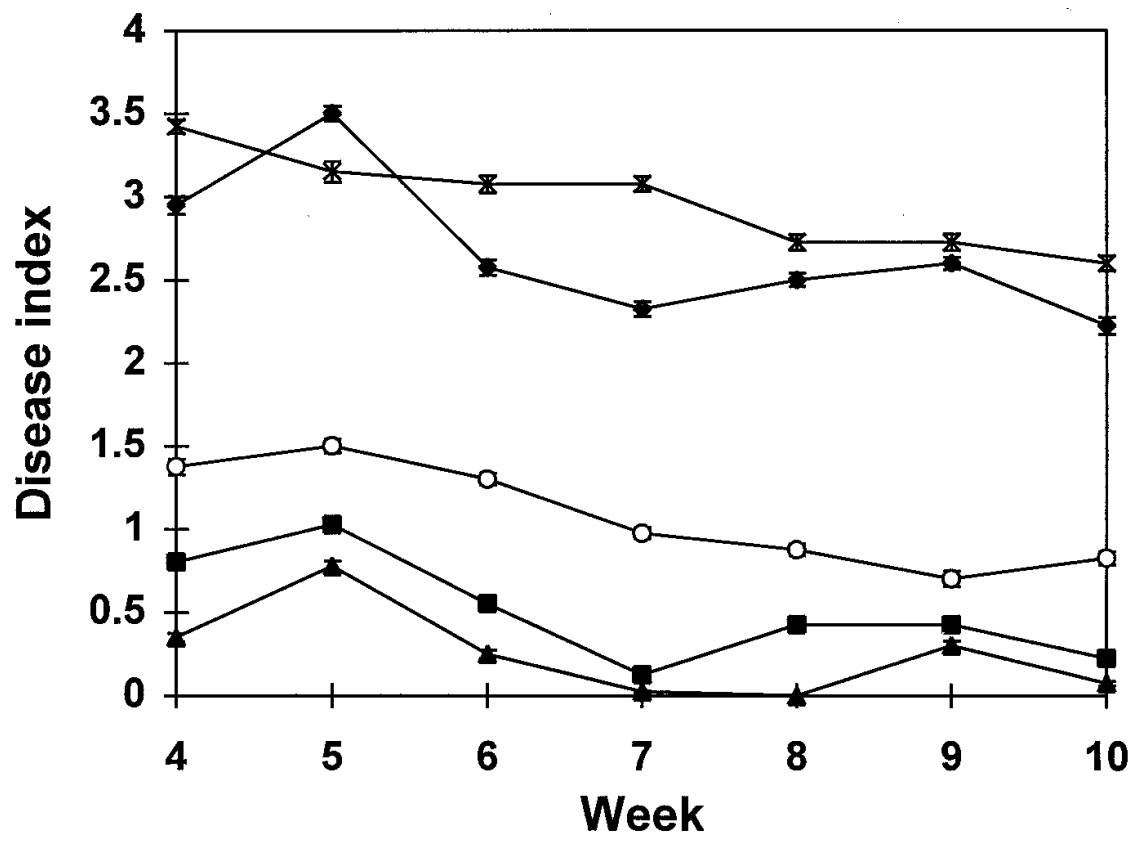

Fig. 1. Disease indices of satellite-transgenic tomato lines $1 \mathrm{~B} 6$ and $3 \mathrm{~B} 1$ and their nontransformed parent plant UC82B and the satellite-transgenic line $2 \mathrm{C} 1$ and its nontransformed parent Lichun. Plants were inoculated with cucumber mosaic virus (CMV), scored visually, and rated on a scale of 0 to 4 for CMV disease severity. Ratings began 4 weeks after transplanting to the field during the 1995 growing season $(0=$ no symptoms, $1=$ mild chlorosis, $2=$ severe chlorosis or mild chlorosis plus shoestring leaves, $3=$ shoestring leaves plus stunting or other deformations, $4=$ severe stunting, necrosis, and/or death. $\bullet=\mathrm{UC} 82 \mathrm{~B}, \boldsymbol{\Delta}=1 \mathrm{~B} 6, \boldsymbol{\square}=3 \mathrm{~B} 1, \times=$ Lichun, $\mathrm{O}=2 \mathrm{C} 1$ ). Bars indicate standard errors of the mean.

Table 1. Correlations ( $r$ values) between 1995 cucumber mosaic virus (CMV) satellite RNA levels (dot blot), virus titers (enzyme-linked immunosorbent assay [ELISA]), disease index, and yield from CMV-inoculated plants of satellite-transgenic UC82B tomato lines 3B1 and 1B6, the satellite-transgenic Lichun line 2C1, and the respective nontransformed parental control lines UC82B and Lichun

\begin{tabular}{lllcc}
\hline & & Genotype & ELISA & Disease index \\
\hline Dot blot & Transgenic & 3B1 & 0.141 & $-0.317^{* * z}$ \\
& Control & 1B6 & $0.255^{* *}$ & $-0.318^{* *}$ \\
& Transgenic & UC82B & -0.035 & -0.164 \\
& Control & Cichun & -0.166 & $-0.208^{* *}$ \\
ELISA & Transgenic & 3B1 & & -0.146 \\
& & 1B6 & & 0.032 \\
& Control & UC82B & & -0.027 \\
& Transgenic & 2C1 & & $0.308^{* *}$ \\
Yield & Control & Lichun & & 0.170 \\
& Transgenic & 3B1 & & $0.225^{*}$ \\
& & 1B6 & & -0.016 \\
& Control & UC82B & & -0.018 \\
& Transgenic & 2C1 & & $-0.51^{* *}$ \\
& Control & Lichun & & $-0.51^{* *}$ \\
\hline
\end{tabular}

z **, * Significant at $P=0.01$ or $P=0.05$, respectively. transgenic tomato plants of the indeterminate Chinese variety Lichun were included in field trials. Transgenic Lichun plants expressed the ameliorative 1-CARNA 5 satellite (CMV associated RNA 5 from CMV strain 1) and were developed by Po Tien, Institute of Microbiology, Academia Sinica, People's Republic of China. Similar procedures for plant transformation, regeneration, and selection were utilized for Lichun as for UC82B, except that the T-DNA did not contain the GUS gene. Two transformants (3B1 and 1B6) from UC82B and one transformant (2C1) from Lichun, all homozygous for the satellite RNA transgene, were advanced to the $R_{3}$ and $R_{4}$ generation for field studies. Homozygous segregants were identified via PCR as described by McGarvey and Kaper (28).

Plants were challenge-inoculated with a purified CMV-1 (23) that had been freed of its satellite RNA. CMV-1 elicits severe shoestring leaves, chlorosis, and stunting in infected tomatoes. Plants at the cotyledon stage, approximately 10 days after sowing, were dusted with 600-mesh Carborundum and mechanically inoculated with a purified virus preparation $(20 \mu \mathrm{g} / \mathrm{ml}$ in $0.03 \mathrm{M}$ $\mathrm{Na}_{2} \mathrm{HPO}_{4}$ salt solution) by rubbing the cotyledons with a cotton swab. Mock-inoculated plants were similarly treated using sterile phosphate buffer instead of virus. Inoculated seedlings were held in growth chambers at $24^{\circ} \mathrm{C}$ with a 16 -h photoperiod for 2 weeks, until nontransformed plants exhibited CMV symptoms, and then maintained in the greenhouse until plants produced four to six true leaves. Prior to transplanting to the field, tissues from inoculated plants were assayed for the presence of viral coat protein via enzymelinked immunosorbent assay (ELISA) as described by Montasser et al. (30). Plants displaying weak positive ELISA results were discarded to ensure uniform infection in field test plants.

Field trial design. Field trials were conducted during the summers of 1994 and 1995 on test plots of sandy loam soils located at the USDA-ARS Beltsville Agricultural Research Center in Beltsville, Maryland. The tests utilized a split-plot design with two treatments (inoculated and mock-inoculated blocks) as main plots, genotypes as subplots, and four replications. Subplots consisted of rows $12 \mathrm{~m}$ long with 20 plants of each genotype and $0.6 \mathrm{~m}$ between plants. Rows within main plots were positioned on $1.5-\mathrm{m}$ centers. Standard horticultural practices for tomato production in Maryland were followed (43). Supplemental trickle irrigation was supplied as needed. Main plots were bordered by single guard rows comprised of the CMV-susceptible tomato varieties PikRite and Red Rock and separated by $3-\mathrm{m}$ alleys. This test area was surrounded on all sides by a 9-m perimeter of guard plants. These guard plants were surrounded in turn by a $9-m$ perimeter of oats (Avena sativa), 
a nonhost crop plant that served as a trap plant to deter transmission of CMV satellite RNA beyond the initial boundaries of the test plot. Surrounding the trap plant boundary, an additional 3$\mathrm{m}$ buffer of guard tomatoes was grown to evaluate potential transmission of satellite RNA beyond the containment of the test plot.

Beginning 4 weeks after planting, and continuing for 7 weeks, individual plants of each genotype within respective treatments were monitored at weekly intervals for CMV symptom development and assayed by ELISA to determine CMV titers. Total nucleic acids were extracted from immature leaf tissue collected at weekly intervals from all CMV-challenged and mock-inoculated plants and assayed for SCARNA 5 sequences. Leaf tissue was stored at $-70^{\circ} \mathrm{C}$ as a $1: 10$ homogenate in coating buffer $\left(0.05 \mathrm{M} \mathrm{NaCO}_{3}, \mathrm{pH} 9.6,2 \%\right.$ polyvinylpyrrolidone [PVP]) used for ELISA. Total nucleic acids were extracted from $200 \mu \mathrm{l}$ of the homogenate by phenol:chloroform extraction and alcohol precipitation of the nucleic acids. The dried pellet was resuspended in $10 \mu \mathrm{l}$ of distilled $\mathrm{H}_{2} \mathrm{O}$, which was applied to nylon membranes in a dot blot assay. CMV-S or CMV-1 satellite RNA was detected using riboprobes labeled with DIG-UTP (Boehringer Mannheim, Indianapolis, IN) from cDNA inserts in the pSP65 plasmid previously described $(29,42)$. Satellite RNA levels were estimated via dot hybridization intensity. In addition to test plants, samples for ELISA and Northern dot blot hybridization assay were collected at harvest from every fifth plant in the guard rows and a random sampling of 200 weeds and plants neighboring the test site for the risk assessment portion of the field study. Total marketable yield for all treatments was determined by recording fruit yield of all plants from two harvests conducted over a 3-week period. Analysis of variance was obtained with the SAS (SAS Institute, Cary, NC) general linear models procedure with treatments and genotypes treated as fixed effects.

\section{RESULTS}

CMV resistance. CMV symptomology, virus titers, and satellite RNA levels were evaluated at weekly intervals beginning 4 weeks after transplanting to the field plots. Since similar results were obtained in 1994 and 1995, only 1995 data are shown. CMV-infected plants of the nontransformed parent lines, UC82B and Lichun, exhibited characteristic CMV symptoms, including mild to severe foliar chlorosis, shoestring leaves, and stunting throughout the growing season (Fig. 1). CMV symptom severity of infected nontransformed parental lines was negatively correlated with fruit yield (Table 1). In contrast, inoculated UC82B satellite-transgenic lines 3B1 and 1B6 developed only mild foliar chlorosis early in the growing season (69 and $43 \%$ of plants, respectively) and subsequently recovered 6 to 7 weeks after planting. Relative to $3 \mathrm{~B} 1$ and $1 \mathrm{~B} 6$, the
Lichun satellite-transgenic line $2 \mathrm{C} 1$ displayed more severe viral symptoms $(85 \%$ of plants), including mild leaf shoestring in approximately $3 \%$ of infected plants.

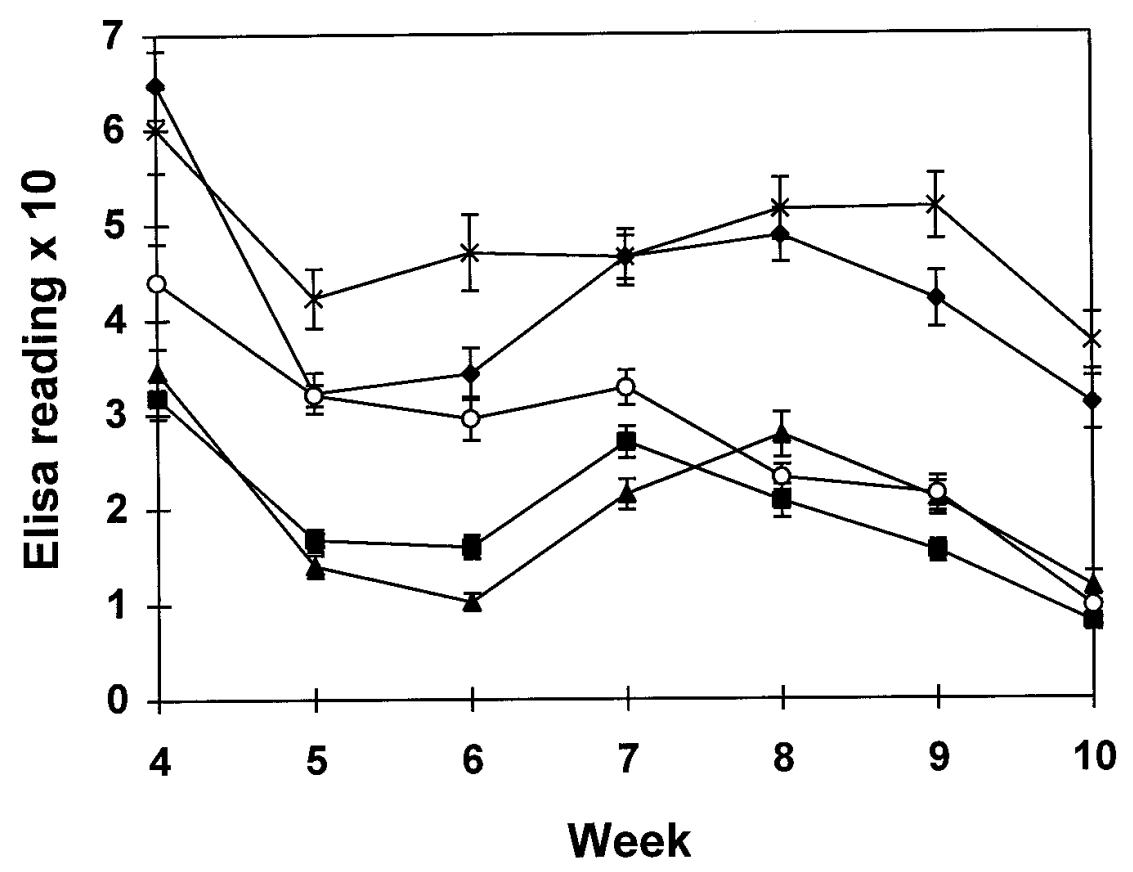

Fig. 2. Changes in virus titer of nontransformed UC82B and Lichun tomato and the satellite-transgenic lines 1B6, 3B1, and 2C1. Plants were inoculated with cucumber mosaic virus (CMV), and virus titers were determined at regular intervals throughout the 1995 growing season using enzymelinked immunosorbent assay (ELISA). ELISA levels are expressed as the ELISA reading output from Biolinx software (Dynatech Laboratories, Chantilly, VA) $\times 10$. Sampling for ELISA began 4 weeks after transplanting to the field $(\bullet=\mathrm{UC} 82 \mathrm{~B}, \boldsymbol{\Delta}=1 \mathrm{~B} 6, \boldsymbol{\nabla}=3 \mathrm{~B} 1, \times=$ Lichun, $\mathrm{O}=2 \mathrm{C} 1)$. Bars indicate standard errors of the mean.

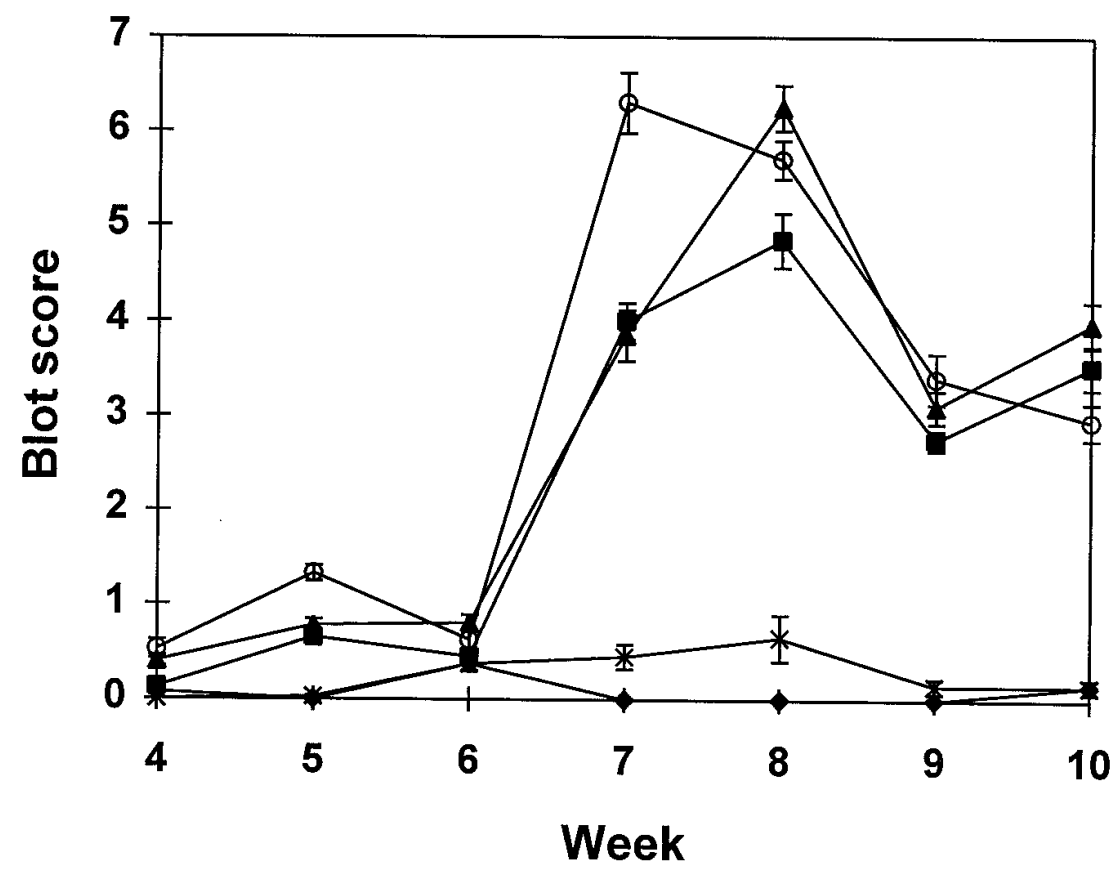

Fig. 3. Changes in cucumber mosaic virus (CMV) Associated RNA 5 (CARNA 5) satellite levels throughout the 1995 growing season in CMV-infected and mock-inoculated plants of satellite-transgenic tomato lines 1B6 and 3B1 and their nontransformed parent line UC82B, and the satellite-transgenic line $2 \mathrm{C} 1$ and nontransformed parent Lichun. CARNA 5 levels are expressed as relative intensity measured visually on a dot blot assay. Sampling for total nucleic acids began 4 weeks after transplanting to the field $(\bullet=\mathrm{UC} 82 \mathrm{~B}, \boldsymbol{\Delta}=1 \mathrm{~B} 6, \boldsymbol{\nabla}=3 \mathrm{~B} 1, \times=$ Lichun, $\mathrm{O}=2 \mathrm{C} 1)$. Bars indicate standard errors of the mean. 
Consistent with CMV symptom expression, higher viral titers were found in infected nontransformed plants of UC82B and Lichun compared with satellite-transgenic plants (Fig. 2). ELISA scores for infected nontransformed parental lines were positively correlated with $\mathrm{CMV}$ symptoms (Table 1). In satellite-transgenic plants, CARNA 5 levels were low during the initial weeks following infection but subsequently increased (Fig. 3). Coincident with peak levels of satellite RNA, virus titers began to decline in protected plants. A significant negative correlation between satellite RNA levels and disease severity was evident in transgenic plants (Table 1). Virus titers during the early stages of infection in the Lichun transgenic line $2 \mathrm{C} 1$ were considerably higher than those observed in the UC82B transgenic lines 1B6 and 3B1 (Fig. 2), suggesting that the SCARNA 5 satellite may confer greater protection than 1-CARNA 5 against CMV1. Differential susceptibility of UC82B and Lichun to CMV does not account for the differences observed in viral titers of transformed plants, since infected nontransformed plants of both lines generally exhibited comparable symptoms and virus titers throughout the growing season. Low levels of satellite RNA detected in $9.6 \%$ of CMV-infected UC82B and Lichun parent lines (Table 2, Fig. 3) may be attributed to aphid transmission or mechanical spread of virus containing satellite RNA between adjacent infected transgenic and nontrans- genic test rows by field workers and local fauna.

Fruit yield. In 1994, total marketable yield of the CMV-inoculated satellitetransgenic UC82B line 3B1 was $57 \%$ greater than that of the CMV-infected nontransformed UC82B parent (Table 3). In 1995 , yields of the inoculated satellitetransgenic UC82B lines 3B1 and 1B6 were 84 and $76 \%$ greater than that of the infected nontransformed UC82B. Similarly, the inoculated transgenic Lichun line $2 \mathrm{C} 1$ showed a $40 \%$ increase in yield over infected nontransformed Lichun. Field observations indicated that fruit set was diminished and delayed in infected nontransgenic lines relative to transgenic plants, accounting for the reduced yields.

A statistically significant $28 \%$ decrease in yield of mock-inoculated 3B1 satellitetransgenic plants relative to mock-inoculated UC82B was observed in 1994; and a $10 \%$, although nonsignificant, decrease was observed in 1995. In 1995, yields of satellite-transgenic 3B1, 1B6, and 2C1 mock-inoculated plants were not significantly different from their respective mock-inoculated UC82B and Lichun parent plants. Analysis of variance for yield indicated significant overall treatment and genotype effects in 1995 (Table 4). Significant effects were limited to treatment by genotype effects in 1994, suggesting that genotype differences were evident only within the respective treatments (i.e., inoculated and mock-inoculated).

Table 2. Cucumber mosaic virus (CMV) and CMV Associated RNA 5 (CARNA 5) presence in nontransgenic UC82B and Lichun control plants and Pik-Rite and Red Rock guard tomatoes as determined by enzyme-linked immunosorbent assay (ELISA) and dot blot

\begin{tabular}{llcc}
\hline & & \multicolumn{2}{c}{ Plants tested (\%) } \\
\cline { 3 - 4 } Variable & Plant source & $\mathbf{1 9 9 4}$ & $\mathbf{1 9 9 5}$ \\
\hline CMV & Mock inoculated controls & 6.9 & 0 \\
& Inner perimeter guard tomato & 7.5 & 5.0 \\
CARNA 5 & Outer perimeter guard tomato & 0 & 0 \\
& Mock inoculated controls & 0 & 0 \\
& CMV inoculated controls & $\mathrm{nd}^{\mathrm{z}}$ & 9.6 \\
& Inner perimeter guard tomato & 0 & 5.0 \\
& Outer perimeter guard tomato & 0 & 0 \\
\hline
\end{tabular}

${ }^{\mathrm{z}}$ Not determined.

Table 3. Fruit yield of satellite-transgenic UC82B tomato lines 3B1 and 1B6, the satellite-transgenic Lichun line $2 \mathrm{C} 1$, and the respective nontransformed parental lines UC82B and Lichun

\begin{tabular}{|c|c|c|c|c|}
\hline \multirow{2}{*}{ Treatment } & & \multirow[b]{2}{*}{ Genotype } & \multicolumn{2}{|c|}{ Yield $(\mathrm{kg}) /$ plant $\pm \mathrm{SE}^{\mathrm{y}}$} \\
\hline & & & 1994 & 1995 \\
\hline \multirow[t]{4}{*}{ CMV-inoculated } & Transgenic & $\begin{array}{l}\text { 3B1 } \\
1 \mathrm{~B} 6\end{array}$ & $\begin{array}{c}3.3 \pm 0.3 \mathrm{ab}^{\mathrm{z}} \\
\ldots\end{array}$ & $\begin{array}{l}4.6 \pm 0.6 \mathrm{a} \\
4.4 \pm 0.4 \mathrm{a}\end{array}$ \\
\hline & Control & UC82B & $2.1 \pm 0.3 \mathrm{c}$ & $2.5 \pm 0.3 \mathrm{c}$ \\
\hline & Transgenic & $2 \mathrm{C} 1$ & $\ldots$ & $4.5 \pm 0.7 \mathrm{a}$ \\
\hline & Control & Lichun & $\ldots$ & $3.2 \pm 0.4 \mathrm{bc}$ \\
\hline \multirow[t]{4}{*}{ Mock-inoculated } & Transgenic & $\begin{array}{l}3 \mathrm{~B} 1 \\
1 \mathrm{~B} 6\end{array}$ & $\begin{array}{c}2.9 \pm 0.1 b c \\
\ldots\end{array}$ & $\begin{array}{l}4.2 \pm 0.2 \mathrm{ab} \\
4.9 \pm 0.5 \mathrm{a}\end{array}$ \\
\hline & Control & UC82B & $4.0 \pm 0.4 \mathrm{a}$ & $4.7 \pm 0.3 \mathrm{a}$ \\
\hline & Transgenic & $2 \mathrm{C} 1$ & $\ldots$ & $4.4 \pm 0.3 \mathrm{a}$ \\
\hline & Control & Lichun & $\ldots$ & $3.9 \pm 0.8 \mathrm{ab}$ \\
\hline
\end{tabular}

${ }^{\mathrm{y}}$ Mean \pm standard error.

${ }^{\mathrm{z}}$ Letters denote least significant difference (LSD) for mean comparison among variables within each year $(P \leq 0.05)$.
Risk assessment. Field test plots were designed to evaluate possible dissemination of satellite RNA within the test area and outside its CMV nonhost oats perimeter. Of the 320 mock-inoculated plants of the nontransformed parental lines in the 1994 test plot, a total of 22 plants $(6.9 \%)$ tested positive for CMV (Table 2). In 1995, none of the mock-inoculated UC82B or Lichun nontransformed plants were symptomatic. In 1994, sixty plants $(7.5 \%)$ of approximately 800 in the inner perimeter of guard tomatoes tested positive for CMV; whereas none of the plants in the outer perimeter exhibited measurable viral titers. For the same period, S-CARNA 5 was not detected in mock-inoculated plants or in outlying border plants inside and outside the nonhost oats perimeter. Likewise, satellite RNA was not detected in weeds sampled within the test site, suggesting that dissemination of satellite RNA was very low or did not occur. In $1995,5 \%$ of the inner perimeter guard tomatoes tested positive for $\mathrm{CMV}$ and another 5\% for CARNA 5 presence, likely due to mechanical spread of virus as noted previously. CMV was not present in tissues sampled from the latter group at levels sufficient for detection via ELISA. Similar occurrences were noted by Crescenzi et al. (4) wherein CARNA 5 was detected without apparent presence of helper virus in weeds bordering CMV-infected field plots. Similarly to 1994 tests, neither CMV nor satellite RNA was detected in outer perimeter guard tomatoes.

\section{DISCUSSION}

Our field trial results demonstrate the protective effects of satellite RNA-mediated CMV control in satellite-transgenic tomato and the commercial potential for use of satellite RNA-mediated protection. Inoculated satellite-transgenic plants displayed only mild or no characteristic CMV symptomology and maintained the yield performance exhibited by uninfected nontransformed parental lines. Despite the fact that infection occurred in satellite-transgenic plants, transgenic plants were asymptomatic for CMV infection at the time of fruit ripening and harvest. In contrast to coat protein-mediated protection, where CMV infection is seemingly prevented or localized at low inoculum concentrations, satellite RNA-mediated protection allows CMV infection and is characterized by a delay in the tolerance response. This occurs because the helper virus is required for the satellite RNA replication in transgenic plants expressing satellite RNA. Viral titers increase upon infection, and mild symptoms may occur until the satellite RNA is produced in sufficient quantity to protect against the invading virus (40). Available evidence suggests a simple model for the satellite RNA-mediated protection wherein a decrease in viral replication, following competition by the sat- 
ellite RNA, could result in symptom attenuation and low levels of CMV genomic and satellite RNA accumulation for the life of the plant (19). Whereas satellite-mediated protection provides resistance to satellite-free CMV isolates as well as CMV isolates containing necrogenic satellite, conventional cross-protection or coat protein-mediated protection is ineffective against challenge infection by $\mathrm{CMV}$-containing necrogenic satellite (30).

Importantly, yield of infected satellitetransgenic lines did not differ significantly from mock-inoculated parent lines in 1994 or 1995 , demonstrating that protection in transgenic plants was sufficient to maintain yield potentials equivalent to those of parent lines in the absence of CMV disease pressure. Significantly decreased yields of mock-inoculated 3B1 satellite-transgenic plants relative to mock-inoculated UC82B were observed in 1994. In mock-inoculated treatments of previous satellite RNA-mediated cross-protection tests, reduced yields of protected plants were also observed relative to untreated plants, likely due to the low level of infection that occurs in cross-protected plants. Since low levels of infection do not occur in protected mock-inoculated satellite-transgenic plants, our observations may be attributed to an effect of the transgene's location in the plant DNA (30).

The relatively high rate of mutation that may occur during RNA replication has raised concerns regarding the safety of satellite RNA-based control of plant viruses (39). A single-point mutation may induce nonnecrogenic satellite RNA to become necrogenic. This has been described for two ameliorative satellite RNA variants $(32,39)$. Considerable sequence variation commonly exists between necrogenic and nonnecrogenic forms $(20,42)$. For example, the S-CARNA 5 and 1CARNA 5 constructs utilized in our field tests differed from the necrogenic CARNA 5 in at least 45 and 26 critical positions $(1,3)$ located in domains that distinguish necrosis-inducing CARNA 5 variants from those that attenuate infection $(22,37)$. The occurrence of several simultaneous base changes, together with counterselection pressures operating at the molecular level as noted by Tepfer (39) and changes that may be occurring naturally, make reversion of benign satellite RNAs to their necrogenic form a rare event. In contrast with the preinoculation technology wherein replication of the CMV helper virus and the satellite RNA occurs, satellite RNA replication does not occur in transgenic plants without infection, thereby minimizing the possible buildup and dissemination of potentially harmful satellite RNA variants.

The successful applications of satellitemediated control of CMV address a number of the concerns regarding the safety of satellite RNA release. Satellite RNA preinoculation technology has been applied in the People's Republic of China since 1983 under field conditions where CMV infestations are endemic to protect tomato, pepper, cucurbits, cabbage, and tobacco on over 10,000 ha in at least 16 localities with outstanding results (40). In Japan, biocontrol of CMV via preinoculation with satellite RNA plus helper virus was introduced commercially in 1993 to protect fieldgrown tomatoes (H. Sayama, personal communication).

The results of our field tests using transgenic plants expressing satellite RNA, albeit on a smaller scale, support the riskassessment evaluations based upon previous applications of the preinoculation technology in East Asia (40). Dissemination of satellite RNA in our test sites was low. To date, none of the ameliorative satellite RNAs used in our satellite-transgenic plant trials or in reported preinoculation protected acreage has damaged protected crops or surrounding species neighboring the test site. No new types of disease, harmful necrogenic satellite RNA variants, or increased satellite RNA titers that could result from possible spread and replication of new variants were detected in our test sites or in extensive field surveys of satellite RNA-protected areas in China (40). In Italy, detectable levels of CMV-S or its satellite RNA did not spread from tomato plants protected by preinoculation technology to susceptible crops in the immediate vicinity (4). Results obtained from preinoculation protected tomato acreage suggested that viruliferous aphids lose their virus-transmitting ability after feeding on protected plants (11). Tien and $\mathrm{Wu}(40)$

Table 4. Analysis of variance mean squares for yield of satellite-transgenic and nontransformed control tomato plants in 1994 and 1995 field test plots

\begin{tabular}{|c|c|c|c|c|c|c|}
\hline \multirow[b]{2}{*}{ Source } & \multicolumn{3}{|c|}{1994} & \multicolumn{3}{|c|}{1995} \\
\hline & df & Mean square & $F$ & df & Mean square & $F$ \\
\hline Block (B) & 3 & 0.38 & 1.52 & 3 & 7.43 & $10.73 * * * \mathrm{y}$ \\
\hline Treatment $(\mathrm{T})$ & 1 & 2.37 & $5.69^{z}$ & 1 & 5.11 & $219.13 * * * \mathrm{z}$ \\
\hline $\mathrm{T} \times \mathrm{B}$ & 3 & 0.42 & 1.64 & 3 & 0.02 & 0.03 \\
\hline Genotype (G) & 1 & 0.03 & 0.13 & 4 & 2.41 & $3.48 *$ \\
\hline $\mathrm{T} \times \mathrm{G}$ & 1 & 5.55 & $21.88 * *$ & 4 & 1.67 & 2.41 \\
\hline Error & 6 & 0.25 & & 24 & 0.69 & \\
\hline
\end{tabular}

y ***, **, * Significant at $P=0.001, P=0.01$, or $P=0.05$, respectively.

${ }^{\mathrm{z}} F$ values of probability using treatment $\times$ block as the error term. noted that mild strains of CMV utilized for biocontrol were transmitted with lower efficiency by aphids.

At present, more than 30 satellite RNAs associated with different crop viruses are known that may or may not modulate the symptoms of the viruses with which they are associated (2). Our results using transgenic plants expressing satellite RNA and those documented over the past 15 years using the preinoculation technology demonstrate the efficacy of CMV satellite RNA-based protection for control of CMV. This novel approach using CARNA 5 satellites to confer tolerance to CMV alleviated foliar viral symptom expression and maintained significantly greater marketable fruit yield in satellite-transgenic plants relative to unprotected plants. The discovery of ameliorative satellite RNAs associated with other viral pathogens may extend this technology to other crop diseases.

\section{LITERATURE CITED}

1. Avila-Rincon, M. J., Collmer, C. W., and Kaper, J. M. 1986. In vitro translation of cucumoviral satellites. I. Purification and nucleotide sequence of cucumber mosaic virusassociated RNA 5 from cucumber mosaic virus strain S. Virology 152:446-454.

2. Collmer, C. W., and Howell, S. H. 1992. Role of satellite RNA in the expression of symptoms caused by plant viruses. Annu. Rev. Phytopathol. 30:419-442.

3. Collmer, C. W., Tousignant, M. E., and Kaper, J. M. 1983. Cucumber mosaic virus associated RNA 5. X. The complete nucleotide sequence of a CARNA 5 incapable of inducing tomato necrosis. Virology 127:230-234.

4. Crescenzi, A., Barbarossa, L., Gallitelli, D., and Martelli, G. P. 1993. Cucumber mosaic cucumovirus populations in Italy under natural epidemic conditions and after a satellitemediated protection test. Plant Dis. 77:28-33.

5. Cuozzo, M., O’Connell, K. M., Kaniewski, W., Fang, R. X., Chua, N., and Tumer, N. E. 1988. Viral protection in transgenic tobacco plants expressing the cucumber mosaic virus coat protein or its antisense RNA. Bio/Technology 6:549-557.

6. Daniels, J., and Campbell, R. N. 1992. Characterization of cucumber mosaic virus isolates from California. Plant Dis. 76:1245-1250.

7. Davis, R. F., and Shifriss, O. 1983. Natural virus infection in silvery and nonsilvery lines of Cucurbita pepo. Plant Dis. 67:379-380.

8. Fuchs, M., Provvidenti, R., Slightom, J. L., and Gonsalves, D. 1996. Evaluation of transgenic tomato plants expressing the coat protein gene of cucumber mosaic virus strain WL under field conditions. Plant Dis. 80:270-275.

9. Gallitelli, D., DiFranco, A., Vovlas, C., Crescenzi, A., and Ragozzino, A. 1988. Una grave virosi del pomodoro in Italia meridionale. Inform. Agrario 44:67-70.

10. Gallitelli, D., DiFranco, A., Vovlas, C., and Kaper, J. M. 1988. Infezioni miste del virus del mosaico del cetriolo (CMV) e di potyvirus in colture ortive di Puglia e Basilicata. Inform. Fitopatol. 38:57-64.

11. Gallitelli, D., Vovlas, C., Martelli, G., Montasser, M. S., Tousignant, M. E., and Kaper, J. M. 1991. Satellite-mediated protection of tomato against cucumber mosaic virus: II. Field test under epidemic conditions in southern Italy. Plant Dis. 75:93-95.

12. Gonsalves, C., Xue, B., Yepes, M., Fuchs, M., Ling, K., Namba, S., Chee, P., Slightom, J. L., and Gonsalves, D. 1994. Transferring the cu- 
cumber mosaic virus-white leaf strain coat protein gene into Cucumis melo L., and evaluating transgenic plants for protection against infections. J. Am. Soc. Hortic. Sci. 119:345-355.

13. Gonsalves, D., Chee, P., Provvidenti, R., Seem, R., and Slightom, J. L. 1992. Comparison of coat protein-mediated and geneticallyderived resistance in cucumbers to infection by cucumber mosaic virus under field conditions with natural challenge inoculations by vectors. Bio/Technology 10:1562-1570.

14. Gonsalves, D., Provvidenti, R., and Edwards, M. C. 1982. Tomato white leaf: The relation of an apparent satellite RNA and cucumber mosaic virus. Phytopathology 72:1533-1538.

15. Harrison, B. D., Mayo, M. A., and Baulcombe, D. C. 1987. Virus resistance in transgenic plants that express cucumber mosaic virus satellite RNA. Nature 328:799-802.

16. Jacquemond, M., and Leroux, J. 1982. L'ARN satellite du virus de la mosaique du concombre II. Etude de la relation virus-ARN satellite chez divers hotes. Agronomie 2:55-62.

17. Jorda, C., Alfaro, A., Aranda, M. A., Moriones, E., and Garcia-Arenal, F. 1992. An epidemic of cucumber mosaic virus plus satellite RNA in tomatoes in eastern Spain. Plant Dis. 76:363-366.

18. Kaper, J. M. 1992. Satellite-induced viral symptom modulation in plants: A case of nested parasitic nucleic acids competing for genetic expression. Res. Virol. 143:5-10.

19. Kaper, J. M. 1993. Satellite-mediated symptom modulation: An emerging technology for the biological control of viral crop disease. Microb. Releases 2:1-9.

20. Kaper, J. M., and Collmer, C. W. 1988. Modulation of viral plant diseases by secondary RNA agents. Pages 171-194 in: RNA Genetics. Vol. III: Variability of RNA Genomes. E. Domingo, J. Holland, and P. Ahlquist, eds. CRC Press, Boca Raton, FL.

21. Kaper, J. M., Gallitelli, D., and Tousignant, M. E. 1990. Identification of a 334-ribonucleotide viral satellite as principal aetiological agent in a tomato necrosis epidemic. Res. Virol. 141:81-95.

22. Kaper, J. M., Tousignant, M. E., and Steen, M. T. 1988. Cucumber mosaic virus associated RNA 5. XI. Comparison of 14 CARNA 5 variants relates ability to induce tomato ne- crosis to a conserved nucleotide sequence. Virology 163:284-292.

23. Kaper, J. M., Tousignant, M. E., and Thompson, S. M. 1981. Cucumber mosaic virus-associated RNA 5. VIII. Identification and partial characterization of a CARNA 5 incapable of inducing tomato necrosis. Virology 114:526-533.

24. Kaper, J. M., and Waterworth, H. E. 1977. Cucumber mosaic virus-associated RNA 5: Causal agent for tomato necrosis. Science 196:429-431

25. Kearney, C. M., Zitter, T. A., and Gonsalves, D. 1990. A field survey for serogroups and satellite RNA of cucumber mosaic virus. Phytopathology 80:1238-1243.

26. Kim, S. J., Paek, K. H., and Kim, B. D. 1995. Delay of disease development in transgenic petunia plants expressing cucumber mosaic virus $\mathrm{I}_{17} \mathrm{~N}$-satellite RNA. J. Am. Soc. Hortic. Sci. 120:353-359.

27. Marrou, J., Duteil, H., Lot, H., and Clerjeau, M. 1973. La necrose de la tomate: Une grave virose des tomates cultivees en plein champ. Pepin. Hortic. Maraich. 137:37.

28. McGarvey, P. B., and Kaper, J. M. 1991. A simple and rapid method for screening transgenic plants using the polymerase chain reaction. BioTechniques 11:428-432.

29. McGarvey, P. B., Montasser, M. S., and Kaper, J. M. 1994. Transgenic tomato plants expressing satellite RNA are tolerant to some strains of cucumber mosaic virus. J. Am. Soc. Hortic. Sci. 119:642-647.

30. Montasser, M. S., Tousignant, M. E., and Kaper, J. M. 1991. Satellite-mediated protection of tomato against cucumber mosaic virus: I. Greenhouse experiments and simulated epidemic conditions in the field. Plant Dis. 75:86-92.

31. Mossop, D. W., and Francki, R. I. B. 1979. Comparative studies on two satellite RNAs of cucumber mosaic virus. Virology 95:395-404.

32. Palukaitis, P., and Roossinck, M. J. 1996. Spontaneous change of a benign satellite RNA of cucumber mosaic virus to a pathogenic variant. Nat. Biotechnol. 14:1264-1268.

33. Putz, C., Kuszala, J., Kuszala, M., and Spindler, C. 1974. Variation du pouvoir pathogene des isolats du virus de la mosaique du concombre associee a la necrose de la tomate. Ann. Phytopathol. 6:139-154.
34. Sayama, H., Sato, T., Kominato, M., Natsuaki, T., and Kaper, J. M. 1993. Field testing of a satellite-containing attenuated strain of cucumber mosaic virus for tomato protection in Japan. Phytopathology 83:405-410.

35. Sikora, E. J., and Gudauskas, R. T. 1992 Report on cucumber mosaic virus epidemic in field grown tomatoes in Alabama. Pages 110 113 in: Proc. Annu. Tomato Dis. Workshop, 8th, Columbus, $\mathrm{OH}$.

36. Sikora, E. J., Gudauskas, R. T., Murphy, J. F., Porch, D. W., and Lester, D. F. 1993. Report on the virus complex affecting tomatoes in Alabama. Pages 52-54 in: Proc. Annu. Tomato Dis. Workshop, 9th, Indianapolis, IN.

37. Sleat, D. E., and Palukaitis, P. 1990. Site directed mutagenesis of a plant viral satellite RNA changes its phenotype from ameliorative to necrogenic. Proc. Natl. Acad. Sci. USA 87:2946-2950.

38. Suszkiw, J. 1996. Geneplay combats cucumber mosaic virus. Agric. Res. 44:16-18.

39. Tepfer, M. 1993. Viral genes and transgenic plants. Bio/Technology 11:1125-1132.

40. Tien, P., and Wu, G. S. 1991. Satellite RNA for the biological control of plant disease. Pages 321-339 in: Advances in Virus Research. Vol. 39. K. Maramorosch, F. Murphy, and A. Shatkin, eds. Academic Press, New York

41. Tomlinson, J. A. 1987. Epidemiology and control of virus diseases of vegetables. Ann. Appl. Biol. 110:661-681.

42. Tousignant, M. E., and Kaper, J. M. 1993. Cucumber mosaic virus associated RNA 5. XIII. Opposite necrogenicities in tomato of variants with large $5^{\prime}$ half insertion/deletion regions. Res. Virol. 144:349-360.

43. University of Maryland. 1991. Commercia vegetable production recommendations. Univ. Maryland Coop. Ext. Serv. Bull. 236, College Park.

44. Waterworth, H. E., Kaper, J. M., and Tousignant, M. E. 1979. CARNA 5, the small cucumber mosaic virus-dependent replicating RNA, regulates disease expression. Science 204:845-847.

45. Wu, J. M., and Kaper, J. M. 1995. Competition of viral and satellite RNAs of cucumber mosaic virus for replication in vitro by vira RNA-dependent RNA polymerase. Res. Virol. 146:61-67 